\title{
Importance Performance Analysis Model for Implementation in National Education Standards (SNPs)
}

\author{
Endin Mujahidin ${ }^{1}$ \\ Syamsuddin ${ }^{1}$ \\ Immas Nurhayati ${ }^{1}$ \\ Didin Hafidhuddin ${ }^{1}$ \\ Ending Bahruddin ${ }^{1}$ \\ Endri Endri ${ }^{2^{*}}$ \\ ${ }^{1}$ Universitas Ibn Khaldun, Bogor, \\ Jawa Barat 16162, Indonesia \\ ${ }^{2}$ Universitas Mercu Buana, \\ Jakarta 11650, Indonesia \\ *Corresponding Author
}

DOI: https://doi.org/10.36941/ajis-2021-0127

\section{Abstract}

The purpose of this study is to analyse the implementation of three national education standards (SNPs), namely management standards, graduates competency standards, and teacher and education staff at the Ummul Quro (UQ) Islamic school and the Bogor Hajj Persaudaraan Foundation (YPHB) using importanceperformance analysis (IPA) model. This study uses primary data sourced from a questionnaire distributed to thirty respondents. The test results reveal that the application of management standards, graduate competency standards, and standards for teachers and education personnel at Islamic boarding schools UQ and YPHB have been optimal with a level of compatibility between importance and performance at a very good level. The implementation of 3 SNPs in UQ and YPHB based on IPA showed that Islamic education institutions must strive to improve performance through compilation of the respective duties, job description, use of work procedures, and socialization management system and maintain several attributes that have been assessed as good, such as formulate vision and mission, goals, targets and strategic plans, organizational structure, guidelines. The institution also has to maintain the stability of the level of satisfaction with the quality of the performance, implementation of activities according to the agreed program, involvement of community participation and partnerships/school committees, monitoring the implementation of the program.

Keywords: implementation, importance-performance analysis model, national education standards (SNPs), suitability analysis 


\section{Introduction}

Education is a very important aspect that can improve the quality of human life. Education is a manifestation of investment in human resources that will affect the level of life and welfare. Through education, humans learn a variety of knowledge, increase abilities, self-potential, and character building. Education makes humans have a spiritual spirit, good morals, self-control, and skills that are beneficial to themselves, the nation, and the state. The existence of national education in Indonesia serves to develop a positive character and form a good personality in creating a civilized, dignified and intelligent nation. The implementation of education aims to develop the potential and abilities of the community and make it a righteous nation, has noble, healthy, knowledgeable, creative, democratic, and responsible characters. One of the government policies to achieve this goal is to establish National Education Standards (SNP) which aim to educate the nation's life by improving the quality of national education. There are eight aspects in the SNP, namely graduate competency standards, content standards, process standards, teacher and education staff standards, infrastructure standards, management standards, financing standards, and education assessments (Wahyuni, 2016). Content standards include material and the minimum level of graduate competence that must be met. Each type and level of education has certain criteria. Graduate Competency Standards (SKL) include minimum competency standards for primary and secondary education units, groups, and subject graduates. Educational Process Standards include everything related to the learning process which is carried out in an interactive, challenging, inspiring, creative, exploring importance and talents and providing attraction so that students are excited and actively participate in it. Standards Facilities and Infrastructure include the availability of learning facilities both facilities (books, educational media, and other equipment) and infrastructure (buildings, classrooms, administration rooms, library rooms, and others). Management Standards include management on three elements, namely management standards in education units, local government, and government. Education Financing Standards cover various forms of costs for providing education such as operational and investment costs. Education assessment standards are the final evaluation of learning by education units and the government (Silitonga et al., 2020). teacher and education staff standards by applicable regulations (Wahyuni, 2016). Through SNPs, the government's commitment to improving the quality of schools, apart from implementing policies on national education standards, is also realized by allocating government budgets for education which will be used to finance programs to upgrade the existence of qualified education (OECD \& ADB, 2015).

Learning activities in schools are directed at achieving high-quality education by implementing national education standards in various aspects. For some schools, it is difficult to determine educational standards as a reference for conducting education. Policies formulated unilaterally by the government make it difficult for the public to implement these policies, especially in the present (Badrudin, 2017). The difficulty in following the standards set by the government in various ways, for example, the curriculum is caused by many factors, including the limited human resources, both quality, and quantity, capital, technology, quality of education, competition, and others (Rusdiana \& Nasihudin, 2018). The implementation of education in the current era is different from the implementation of education in the past, where the level of school competition was not as high as today, where competition between schools is increasingly open, especially in providing services. Private schools no longer compete with fellow private schools, but also with schools managed by the government. Therefore, if a school wants to get appreciation, recognition, and importance from the community, the school must be able to provide excellent service both academic and non-academic that will motivate and encourage students to be diligent and serious about their studies (Noviyanti et al., 2018) which will increase satisfaction (Sidik et al., 2019; De Jesus Henriques Silva \& Fernandes, 2011). A study that focuses on the aspects of internal motivation, especially those driven by educational service institutions and their impact on user satisfaction, showed that the educational institutions must continue to strive to improve services to students through improving the quality of learning where student satisfaction is largely determined by these two things. (Noviyanti et al., 2018). 
To be able to win the competition and maintain its existence. To maintain the existence of schools during competition, it must be addressed by improving the quality of education (De Jesus Henriques Silva \& Fernandes, 2011). The existence of school accreditation is an indicator of quality as well as a school ranking (Anafinova, 2020). The quality of education in most education delivery in Indonesia is in a low category at the primary, junior high, and senior high school (Sebayang \& Swaramarinda, 2020), especially in Islamic schools. On a national scale, the number of Islamic education institutions as well as their students is very large but they do not have competitiveness because they are of lower quality than other public and private schools, especially at the junior and senior high school levels. Based on the results of the 2019 national exam and the results of UTBK (Computer-Based Written Examination) 2020, the best scores are dominated by public schools and other private schools. The following table 1 shows the data of the 10 best national and private junior and senior high schools based on the average national examination score in 2019.

Table 1: The Best National and Private Junior and Senior High Schools Based on the Average National Examination Score in 2019

\begin{tabular}{rlrlc}
\hline \multirow{2}{*}{ No } & $\begin{array}{l}\text { Yunior High School } \\
\text { School Name }\end{array}$ & Average & $\begin{array}{l}\text { Senior High School } \\
\text { School Name }\end{array}$ & Average \\
\hline 1 & Negeri 5 Yogyakarta & 95,26 & Negeri Unggulan MH Thamrin & 91,96 \\
2 & Unggulan Al-Ya'Lu Jawa Timur & 94,26 & Kristen 1 PENABUR & 90.98 \\
3 & Negeri 4 Pakem Yogyakarta & 94,22 & Santa Ursula & 89.78 \\
4 & Negeri 11 Jakarta & 93,78 & Kristen Yusuf & 88,33 \\
5 & Negeri 8 Yogyakarta & 93,61 & Kanisius & 88 \\
6 & Negeri 1 Surabaya & 93,52 & Labschool Kebayoran & 87,95 \\
7 & Negeri 1 Godean Yogyakarta & 93,02 & Kristen 3 BPK PENABUR & 87,66 \\
8 & Lab.School Kebayoran Jakarta & 92,64 & Kristen 6 BPK PENABUR & 87,55 \\
9 & Lab.School Jakarta & 92,53 & Kristen 8 BPK PENABUR & 86,56 \\
10 & Negeri 255 DKI Jakarta & 92,06 & Negeri 8 & 86,55 \\
\hline
\end{tabular}

Source: Data is processed from various sources (2021)

To be able to compete, Islamic education institutions or Islamic schools must be managed professionally, referring to the standards. In implementing the SNPs, the management of an Islamic school requires full support from the foundation so that the management of the Islam school leads to professional management standards. The purpose of this study is to analyse the policy model of educational foundation management in implementing three national education standards (SNPs), namely management standards, Graduate Competency Standards, teacher and education staff Standards from eight national education standards (SNPs) for the management of Islamic schools at the Ummul Quro (UQ) Islamic School and the Bogor Hajj Brotherhood Foundation (YPHB). The main target of education is to produce comprehensive and quality graduates according to Graduate competency standards (SKL). These three standards are the main keys to the success of educational institutions. Management about how an organization is regulated, directed, coordinated, and evaluated so that all activities lead to organizational goals (Amoli \& Aghashahi, 2016). The competence of graduates is the final target of achieving the educational goals of students. teachers and education personnel as actors in the process and driving the system (Mujahidin \& Hartono, 2020). There are still low teacher qualifications and competencies (Anwar, 2018). The preparation of graduate competency standards (SKL) is a guide in the preparation of school programs that can deliver them to become quality students and be able to compete in life. Management standards are vital for maintaining the survival and reputation of educational institutions (Rusdiana \& Nasihudin, 2018).

Islamic school is one of the education providers which is an important part of the national education system and standards. Along with other public schools, Islamic school strives to create 
smart, competitive and refer to best achievement (Anwar, 2018). The opportunity for success is to take advantage of the potential that is owned in various aspects of the SPNs including a structured curriculum, religion, adequate facilities, extracurricular programs. (Anwar, 2018). Control of the quality of education based on national education standards (Wahyuni, 2016). Several things that determine the quality of educational services in educational institutions are the existence of a clear vision, mission, and institutional objectives which are disseminated to all internal and external stakeholders. Leaders of educational institutions must be a concern and ensure that teaching and learning activities are carried out as well as possible and provide solutions to problems faced in the implementation process (Hapsari et al., 2021). Leaders of educational institutions also need to know what is happening in the classroom. Without this knowledge, it is difficult to identify the various problems faced by teachers and students. Learning leaders need to work closely with students, develop learning techniques and methods as a means of understanding teacher perspectives, and build a useful foundation for making decisions related to the implementation of education in schools (Mujahidin \& Hartono, 2020; Virgiawan et al., 2021). An important and strategic step is to improve the quality of Islamic school management, including entrusting the management of the best education practices to school principals and teachers, being the parties who think about development and determine the direction of school development who are then consulted in meetings with the school committee, pay attention to efforts to provide opportunities for outstanding students through scholarships and so on, provide support for schools' efforts to advance themselves through information technology or infrastructure needed by schools as institutions, thinking about sources of funding so that school activities can be carried out well and teachers get support to carry out creative and importance learning activities in schools as well as school management control.

The implementation of the national education standards (SNPs) in this case is the implementation or application of the national education standards (SNPs) which are strived and carried out by the leaders of Islamic schools to achieve the goals of Islamic education. The purpose of this study is to analyse whether the implementation of national education standards at the senior high school level is by the expectations by looking at the level of suitability between performance and importance using the importance-performance analysis (IPA) model. This article is in four parts. The first part is the background for the selection of research topics and previous research that is relevant to the research topic. The second part describes the data, research sources, and research methods used. The third part discusses the results of data processing and analysis. Meanwhile, the fourth part is a conclusion.

\section{Research Methodology}

To test the implementation of 3 SNPs, the Importance-Performance Analysis (IPA) method is used. The data used in this research was obtained from two Islamic senior high schools namely the Ummul Quro (UQ) and the Bogor Hajj Brotherhood Foundation (YPHB). Several reasons for choosing the Ummul Quro and Bogor Haji Brotherhood Foundation as a source of research data are have been established for a long time, YPHB has been establishing in Bogor in 1995 with 663 student body and UQ has been establishing in 2011 with a big student body of 2236. Both of them have good school performance and achievements at local, national, and international levels, there is no conflict between school and foundation management. These two Islamic schools are full-day schools that integrate general and Islamic learning and using a full-day school system, forward-looking, with organized management. The total number of employees of the Bogor Ummul Quro Foundation is 319 people, while YPHB employees are 215 people. Data collection is carried out through surveys, tracing related files or documents, distributing questionnaires to 30 respondents, and interviewing the main data sources to explore the results of tracing related files or documents and the results of distributing questionnaires, triangulation by interviews with related parties. The 30 respondents include principal officers, deputy principals, teachers, and staff. List of respondents' responses to questions obtained using a five-point Likert scale. Surveys conducted online allow users to assess importance and performance. The purpose of the survey was to highlight important areas for improvement. through 
the IPA model, a two-dimensional grid, divided into four categories: (1) concentrate here; (2) keep up good work; (3) low priority; and (4) overlap conditions. The research instrument that will be followed up in the questions in the questionnaire refers to three national education standards, namely management standards, competency standards for graduates (SKL), and standards for educational and teaching staff which are integrated into the four functions of management, planning, organizing, actuating and controlling as shown in table 2.

\section{Table 2: Research Instrument}

\begin{tabular}{|c|c|c|c|c|}
\hline No & \begin{tabular}{|l|} 
Management \\
Function
\end{tabular} & Management Standards & \begin{tabular}{|l|} 
Competency standards of \\
Graduates
\end{tabular} & $\begin{array}{l}\text { Standards for educational and } \\
\text { teaching staff }\end{array}$ \\
\hline 1 & Planning & $\begin{array}{l}\text { Vision, mission, objectives, targets/goals and } \\
\text { strategic plans, work programs, decision } \\
\text { making, underlying Islamic values }\end{array}$ & \begin{tabular}{|l|} 
Reference source, \\
preparation of indicators, \\
determination and \\
validation of SKL, the \\
underlying Islamic values \\
(basis).
\end{tabular} & $\begin{array}{l}\text { Analysis of the determination of HR } \\
\text { needs, recruitment plans, selection, } \\
\text { management, acceptance, } \\
\text { appointment and dismissal of HR, } \\
\text { underlying Islamic values (bases). }\end{array}$ \\
\hline 2 & Organizing & $\begin{array}{l}\text { Organizational structure, main tasks, } \\
\text { functions / Job description / Division of tasks, } \\
\text { controlling authority and person in charge of } \\
\text { management, management documentation, } \\
\text { working mechanisms/procedures for Islamic } \\
\text { foundations and schools, coordination } \\
\text { mechanisms for Islamic foundations and } \\
\text { schools. }\end{array}$ & $\begin{array}{l}\text { Responsible for the } \\
\text { preparation of SKL, } \\
\text { coordination patterns } \\
\text { assignments, a } \\
\text { mechanism for drafting } \\
\text { SKL. }\end{array}$ & $\begin{array}{l}\text { Providing an understanding of } \\
\text { institutional systems and regulations } \\
\text { to HR, assignments, management, } \\
\text { HR career path patterns, and HR } \\
\text { enhancement and development. }\end{array}$ \\
\hline 3 & Actuating & $\begin{array}{l}\text { Patterns of providing understanding in the } \\
\text { implementation of work programs, } \\
\text { implementation } \\
\text { mechanisms/procedures/work instructions, } \\
\text { implementation notes, and documentation. }\end{array}$ & $\begin{array}{l}\text { SKL details and phasing. } \\
\text { SKL exposure in the } \\
\text { program. } \\
\text { Achievement of SKL in } \\
\text { the program }\end{array}$ & $\begin{array}{l}\text { Providing an understanding of HR } \\
\text { duties, functions, and authorities, } \\
\text { briefings before implementing HR } \\
\text { tasks, HR motivation patterns, HR } \\
\text { rewards, and punishments }\end{array}$ \\
\hline 4 & Controlling & $\begin{array}{l}\text { Kinds and types of meetings, reports, } \\
\text { supervision and monitoring, evaluation, and } \\
\text { follow-up. }\end{array}$ & \begin{tabular}{|l|} 
Supervision of \\
Monitoring Report on \\
implementation \\
Evaluation of \\
implementation and \\
achievement, follow-up of \\
evaluation results
\end{tabular} & $\begin{array}{l}\text { Supervision and Monitoring of HR, } \\
\text { reports, assessment of attendance, } \\
\text { competence, and HR performance. } \\
\text { Evaluation and follow-up. }\end{array}$ \\
\hline
\end{tabular}

Source: Data Proccessed (2021)

The collected data will follow several steps of processing and analysis consisting of the data reduction stage, data display and conclusion verification, and the suitability between expectations and facts, or importance and performance using the Importance Performance Analysis. Importance-Performance analysis (IPA) is a decision-making model that is useful for management as a management tool in formulating management strategies and controlling for inefficiency and user dissatisfaction with company performance so that improvements can be made in the future and increase the company's competitiveness (Ivan, 2015). Performance refers to the quality of performance while the importance represents the user's perception of the importance or not of a thing/product (Yildiz, 2011). The indicators as presented in table 3 .

Table 3: Indicator of Importance and Performance

\begin{tabular}{|c|l|l|}
\hline Value & Importance & Performance \\
\hline $\mathbf{1}$ & Very Insignificant (STP) & Very Not Good (STB) \\
\hline $\mathbf{2}$ & Not Important (TP) & Not Good (TB) \\
\hline 3 & Quite Important (CP) & Good Enough (CB) \\
\hline 4 & Important (P) & Good (B) \\
\hline 5 & Very Important (SP) & Very Good (SB) \\
\hline
\end{tabular}


IPA in a traditional perspective is a graph that connects two variables in a coordinate system where the horizontal axis represents performance, and the vertical axis represents importance which is divided into 4 quadrants (Martilla \& James, 1977). As seen in table 4, quadrant 1 (high importance / low performance) is called " concentrate here" indicates an action that must be corrected immediately. quadrant II shows the advantages of the company where what can be done is to maintain it (high level of importance / high performance). The condition in quadrant III (low importance / low performance), the so-called 'low priority does not indicate a threat to the organization but management can take a strategy to take immediate corrective action. Quadrant IV (low importance / high performance) is called " excessive possibility " which is a condition even though the performance is very good but does not have an impact on increasing the level of user satisfaction, in this situation the manager tries to allocate resources (Ormanovic et al., 2017).

Table 4: Quadrant of The Importance and Performance

\begin{tabular}{|c|c|}
\hline $\begin{array}{c}\text { Quadrant I } \\
\text { Main Priority (Concentrate Here), considered very } \\
\text { important, unsatisfactory performance and focus on } \\
\text { improving quality. }\end{array}$ & $\begin{array}{c}\text { Quadrant II } \\
\text { Maintain Achievement (Keep up to good work), considered } \\
\text { very important, very satisfying performance, focus on } \\
\text { maintaining quality. }\end{array}$ \\
\hline $\begin{array}{c}\text { Quadrant III } \\
\text { Low Priority, considered not important, performance is } \\
\text { not satisfactory }\end{array}$ & $\begin{array}{c}\text { Quadrant IV } \\
\text { Possible Overkill, considered unimportant, satisfactory } \\
\text { performance }\end{array}$ \\
\hline
\end{tabular}

IPA as a tool of management identifies the strengths and weaknesses of the organization to improve organizational performance and increase satisfaction (Martilla \& James, 1986). IPA is a method that is easy to use, quite simple, and practical. IPA is applied in various fields of life, health (MarkaziMoghaddam et al., 2019), computer engineering (Pahala et al., 2021; Hsiu Yuan Hu et al., 2009), transportation (Javad et al., 2020), ecology (Das \& Basu, 2020), economics and business (Susanto et al., 2020; Akhil \& Suresh, 2021), Government (Wong et al., 2011) and education (Chi-Cheng Chang, 2014; Lakkoju, 2016; Saggaf et al., 2017; Alberty \& Mihalik, 1989). About education, IPA is implemented in evaluating the curriculum where the results can be used to improve the curriculum. Evaluation steps that can be taken consist of the goals and objectives of determining the curriculum, conducting focus group discussions to get input from stakeholders or users, determining and implementing and refining the curriculum (Chi-Cheng Chang, 2014). IPA is also used to analyse variables affecting student preferences as an indicator of the importance and how educational regulations affect performance variables (Alberty \& Mihalik, 1989). Importance-Performance Analysis (IPA) is used to measure the benefits of digital government services for users where testing is carried out using five Likert scales. Grandparent allows users to judge importance and benefits or satisfaction. In addition, it is used as an evaluation material for which attributes are good and which attributes must be corrected immediately. The results of the research help develop future egovernment strategies (Wong et al., 2011).

The IPA model will be used in the study to test the implementation of 3 SNPs in the selected sample, namely the Ummul Quro education institution and YPHB. Using the IPA method in this research is because assessing the implementation of the 3 SNPs is easy in understanding consumer acceptance with a cost that is not too expensive (Martilla \& James, 1986). To find the level of suitability, a table of data recapitulation of the level of performance (X-axis) and the level of importance / Y axis is prepared. The level of suitability is the result of a comparison between the performance score and the importance score. To find out the performance of the management of educational foundations and their staff is by the importance of school leaders/teacher/employees. X is the level of performance on the quality of management of educational foundations that provides satisfaction, while $\mathrm{Y}$ is the level of importance. The formula used is: $T K_{i}=\frac{X_{i}}{Y_{i}} \times 100$

Where:

$\mathrm{TKi}=$ Suitability level of respondents. 
$\mathrm{Xi}=$ Performance appraisal score on management quality points.

$\mathrm{Yi}=$ Score of importance rating against management quality points.

The next step is to analyse the quadrant by calculating the average rating of performance (Xi) and importance (Yi) and for each attribute item with the formula: $\overline{X \imath}=\frac{\sum_{i=1}^{k} X i}{n}$

Where:

$\mathrm{n}=$ Number of respondents

$\overline{X_{\iota}}=$ The average weight of the i-th performance attribute rating

$\bar{Y} \iota=\frac{\sum_{i=1}^{k} Y i}{n}$

Where:

$\bar{Y} \iota=$ The average weight of the rating level of the importance attribute ith

The recapitulation of the management standards attributes score is based on the level of suitability between the level of importance and performance. Overall assessment criteria are 0.81 1.00 (very good), 0.66 - o.8o (good), 0.51 - 0.65 (fairly good), 0.35 - 0.50 (poor) and o.0o - 0.34 (very not good).

\section{Results and Discussion}

Both Ummul Quro and Bogor Hajj Brotherhood Foundation (YPHB) have a mission as an international standard leading institution for the formation of the Qur'an generation as the future generation and a vision of organizing superior, quality, and international standards Islamic education, developing professional da'wah and social institutions as a pioneer in education and community empowerment. The strategy for developing competency, performance, and employee welfare is implemented through a strategic program to increase competency standards and employee performance appraisals, maintain the maximum employee ratio, improve service units and develop business and develop employee cooperatives. The foundation establishes policies, targets, regulations, and provisions in terms of achieving the competency standards for graduates (SKL) in particular for high school education units. To find out more about the implementation of 3 integrated with four functions of management in UQ and YPHB, table 5 below show the attribute of implementation 3 SNPs integrated with four functions of management asked to respond.

Table 5: Management Functions and Attributes at 3 SNPs (Management Standards, Competencies of Graduates and Teacher and Education Staff).

\begin{tabular}{|c|c|c|c|c|c|}
\hline \multirow{2}{*}{$\begin{array}{l}\text { Management } \\
\text { Function }\end{array}$} & \multirow{2}{*}{ No. } & \multirow{2}{*}{$\begin{array}{c}\text { Number of } \\
\text { attributes }\end{array}$} & \multicolumn{3}{|c|}{ Attribute } \\
\hline & & & Management & Competence of Graduates & Teacher and Education Staff \\
\hline \multirow{4}{*}{ Planning } & 1 & $\mathrm{~A}_{1}$ & $\begin{array}{l}\text { Vision \& Mission } \\
\text { Formulation } \\
\end{array}$ & Attitudes, knowledge, and skills. & $\begin{array}{c}\text { Employment guidelines and } \\
\text { regulations }\end{array}$ \\
\hline & 2 & $\mathrm{~A} 2$ & $\begin{array}{l}\text { Purpose of the Foundation } \\
\text { / School }\end{array}$ & SKL indicators & $\begin{array}{c}\text { Employee recruitment, } \\
\text { management, and dismissal } \\
\text { mechanisms. }\end{array}$ \\
\hline & 3 & $\mathrm{~A}_{3}$ & $\begin{array}{l}\text { Targets \& Strategic } \\
\text { Planning }\end{array}$ & $\begin{array}{l}\text { Determination of SKL } \\
\text { achievement targets }\end{array}$ & $\begin{array}{c}\text { Determination of qualifications and } \\
\text { competencies of educators and } \\
\text { educational personnel }\end{array}$ \\
\hline & 4 & $\mathrm{~A}_{4}$ & $\begin{array}{l}\text { Program and Work } \\
\text { Planning }\end{array}$ & Evaluation model. & $\begin{array}{c}\begin{array}{c}\text { Submission of the needs of Teacher } \\
\text { and Education Staff }\end{array} \\
\end{array}$ \\
\hline \multirow{4}{*}{ Organizing } & 5 & A1 & Organization Structure & $\begin{array}{l}\text { The structure of the person in } \\
\text { charge of SKL formulation }\end{array}$ & $\begin{array}{l}\text { Employee work agreements and } \\
\text { commitments }\end{array}$ \\
\hline & 6 & $\mathrm{~A}_{2}$ & Job Description & $\begin{array}{l}\text { Determination of the SKL } \\
\text { drafting team. }\end{array}$ & $\begin{array}{c}\text { Dissemination of policies, } \\
\text { guidelines, and staffing regulations }\end{array}$ \\
\hline & 7 & $\mathrm{~A}_{3}$ & $\begin{array}{l}\text { Management system } \\
\text { socialization }\end{array}$ & $\begin{array}{l}\text { Division of tasks for the } \\
\text { formulation and preparation of } \\
\text { SKL. }\end{array}$ & $\begin{array}{l}\text { Explanation of the structure of the } \\
\text { unit/section, and its main functions }\end{array}$ \\
\hline & 8 & $\mathrm{~A}_{4}$ & $\begin{array}{l}\text { Coordination between } \\
\text { fields of work }\end{array}$ & $\begin{array}{l}\text { Reference sources, guidelines, } \\
\text { SKL preparation techniques. }\end{array}$ & $\begin{array}{l}\text { Implementation of DIKLAT and } \\
\text { employee coaching. }\end{array}$ \\
\hline
\end{tabular}




\begin{tabular}{|c|c|c|c|c|c|}
\hline \multirow{4}{*}{ Actuating } & 9 & $A_{1}$ & $\begin{array}{l}\text { Guidelines for the } \\
\text { implementation of duties }\end{array}$ & $\begin{array}{l}\text { The target time for the } \\
\text { formulation/preparation of the } \\
\text { SKL }\end{array}$ & $\begin{array}{l}\text { Pedagogic, personal, professional, } \\
\text { and social competence }\end{array}$ \\
\hline & 10 & $\mathrm{~A} 2$ & $\begin{array}{c}\text { Mechanisms / procedures / } \\
\text { work instructions }\end{array}$ & Socialization of SKL formulation & $\begin{array}{l}\text { Optimization of task } \\
\text { implementation }\end{array}$ \\
\hline & 11 & $\mathrm{~A}_{3}$ & $\begin{array}{c}\text { Suitability of program } \\
\text { implementation }\end{array}$ & Implementation of SKL & $\begin{array}{l}\text { Optimization of attendance and } \\
\text { performance }\end{array}$ \\
\hline & 12 & $\mathrm{~A}_{4}$ & $\begin{array}{c}\text { Participation of partners / } \\
\text { community / school } \\
\text { committee. }\end{array}$ & $\begin{array}{l}\text { Recording of SKL achievement } \\
\text { results. }\end{array}$ & $\begin{array}{l}\text { Consistent application of reward } \\
\text { and punishment. }\end{array}$ \\
\hline \multirow{4}{*}{ Controlling } & 13 & $A_{1}$ & $\begin{array}{c}\text { Evaluation of work } \\
\text { program implementation }\end{array}$ & $\begin{array}{l}\text { Supervision of program } \\
\text { implementation. }\end{array}$ & $\begin{array}{l}\text { Periodic monitoring of work/task } \\
\text { implementation. }\end{array}$ \\
\hline & 14 & $\mathrm{~A}_{2}$ & $\begin{array}{l}\text { Supervision of work for } \\
\text { each section }\end{array}$ & Evaluation of SKL achievements. & $\begin{array}{l}\text { Periodic supervision of the } \\
\text { implementation of duties. }\end{array}$ \\
\hline & 15 & $\mathrm{~A}_{3}$ & $\begin{array}{l}\text { Achievement of main } \\
\text { duties and functions }\end{array}$ & SKL achievement reporting. & $\begin{array}{l}\text { Evaluation of task implementation } \\
\text { periodically. }\end{array}$ \\
\hline & 16 & $\mathrm{~A}_{4}$ & $\begin{array}{l}\text { Preparation of reports and } \\
\text { recommendations }\end{array}$ & $\begin{array}{l}\text { Preparation of reports and } \\
\text { recommendations. }\end{array}$ & $\begin{array}{l}\text { Preparation of reports and } \\
\text { recommendations. }\end{array}$ \\
\hline
\end{tabular}

\section{Source: Data Processed (2021)}

Based on the results of questionnaire data processing using a Likert scale, it can be seen that the level of suitability (Tki) between the level of importance and the level of performance in the application of management functions on 3 SNPs standards for management, the competence of graduates and teacher and education staff as presented in table 6. The level of Suitability is expressed in a percentage obtained from the comparison of the level of performance (Xi) with the level of importance (Yi).

Table 6: The Level of Suitability of Management Standard, The Competence of Graduates Standards, and The Educator and Education Standards.

\begin{tabular}{|c|c|c|c|c|c|c|c|c|}
\hline \multirow{3}{*}{$\begin{array}{l}\text { Management } \\
\text { Function }\end{array}$} & \multirow{3}{*}{ No } & \multirow{3}{*}{$\begin{array}{l}\text { Number of } \\
\text { Attributes }\end{array}$} & \multicolumn{6}{|c|}{ The Level of Suitability (Tki) (\%) } \\
\hline & & & \multicolumn{2}{|c|}{$\begin{array}{c}\text { Competency } \\
\text { Management Standards }\end{array}$} & \multicolumn{2}{|c|}{$\begin{array}{c}\text { Graduates of } \\
\text { Educators Standards }\end{array}$} & \multicolumn{2}{|c|}{$\begin{array}{c}\text { Teacher and Education } \\
\text { Staff Standards }\end{array}$} \\
\hline & & & Ummul Quro & YPHB & Ummul Quro & YPHB & Ummul Quro & YPHB \\
\hline \multirow{4}{*}{ Planning } & 1 & $\mathrm{~A}_{1}$ & 92,67 & 98,00 & 91,73 & 94,67 & 79,87 & 94,00 \\
\hline & 2 & A2 & 92,62 & 99,33 & 91,73 & 94,67 & 79,19 & 94,00 \\
\hline & 3 & $A_{3}$ & 88,59 & 100,00 & 86,89 & 93,33 & 81,76 & 93,33 \\
\hline & 4 & $\mathrm{~A}_{4}$ & 87,92 & 100,00 & 88,28 & 92,00 & 77,03 & 93,33 \\
\hline \multirow{4}{*}{ Organizing } & 5 & A1 & 87,16 & 97,33 & 86,81 & 94,00 & 87,16 & 84,67 \\
\hline & 6 & $\mathrm{~A} 2$ & 76,51 & 98,67 & 86,81 & 94,00 & 76,35 & 99,33 \\
\hline & 7 & $\mathrm{~A}_{3}$ & 79,59 & 98,00 & 88,11 & 93,33 & 79,45 & 99,33 \\
\hline & 8 & $\mathrm{~A}_{4}$ & 80,82 & 97,33 & 83,92 & 89,33 & 83,67 & 99,33 \\
\hline \multirow{4}{*}{ (Actuating) } & 9 & $\mathrm{~A} 1$ & 82,07 & 99,33 & 84,62 & 92,00 & 82,19 & 100,00 \\
\hline & 10 & $\mathrm{~A} 2$ & 80,95 & 99,33 & 84,72 & 92,67 & 85,62 & 100,00 \\
\hline & 11 & $\mathrm{~A}_{3}$ & 88,73 & 100,68 & 84,14 & 90,00 & 85,14 & 100,00 \\
\hline & 12 & $\mathrm{~A}_{4}$ & 88,03 & 100,00 & 88,28 & 90,00 & 75,17 & 100,00 \\
\hline \multirow{4}{*}{ Controlling } & 13 & A1 & 85,52 & 98,00 & 87,50 & 86,00 & 88,89 & 95,33 \\
\hline & 14 & $\mathrm{~A} 2$ & 82,07 & 97,33 & 84,93 & 89,33 & 86,30 & 90,00 \\
\hline & 15 & $\mathrm{~A}_{3}$ & 80,00 & 93,33 & 85,62 & 82,67 & 85,62 & 91,33 \\
\hline & 16 & $\mathrm{~A}_{4}$ & 85,05 & 92,00 & 91,72 & 80,67 & 82,52 & 84,00 \\
\hline Average of Suitability & & & 84,89 & 98,04 & 87,24 & 93,45 & 82,25 & 94,88 \\
\hline
\end{tabular}

Source: Data Processed (2021)

To find out the difference of the average level of suitability between UQ and YPHB in 
implementation 3 SNPs, a different test on the average level of suitability between UQ and YPHB in implementation 3 SNPs is carried out as presented in Table 7. The average difference test shows that the mean return difference of management standards, competency standards, and educator and education standards between UQ and YPHB is significant, indicated by the p-value < alpha (5\%) and $\mathrm{t}$ stat $>\mathrm{t}$ critical. Thus, it can be stated that the implementation of 3 SNPs at YPHB is better than UQ.

Table 7: The Different Tests on The Average Level of Suitability between UQ and YPHB in Implementation 3 SNPs

\begin{tabular}{|c|c|c|c|c|c|c|}
\hline & \multicolumn{2}{|c|}{ Management Standards } & \multicolumn{2}{|c|}{ Graduate Competency Standard } & \multicolumn{2}{|c|}{ Teacher and Education Staff } \\
\hline & Ummul Quro & YPHB & Ummul Quro & YPHB & Ummul Quro & YPHB \\
\hline Mean & 84,8938 & 98,04125 & 87,238125 & 90,54188 & 82,24563 & 94,87375 \\
\hline T Stat & 9,84964 & & 2,65513412 & & $-7,48624$ & \\
\hline P Value & $3,25 \mathrm{E}-11$ & & 0,00628327 & & $1,20 \mathrm{E}-\mathrm{o} 8$ & \\
\hline t Critical & 1,697261 & & 1,69726089 & & 1,697261 & \\
\hline
\end{tabular}

\section{Source: Data Processed (2021)}

In general, the quality performance of UQ management standards is in the very good category. 5 (five) attributes still need to be optimized, namely no.6 A2 organization, with a $76.51 \%$ level of Suitability; No. 7 organizing $A_{3}$, with a suitability level of $79.59 \% ; 8$ organization $A_{4}$, with a Suitability level of 80.82; No.10 implementation of A2, with a Suitability level of 80.95; and no.16 supervision $\mathrm{A}_{4}$, with a Suitability level of $80.00 \%$. The overall quality performance of the graduate competency standards is very good with a score above 8o. The standard of teacher and education staff is in the very good category. Six attributes still need to be optimized. Number 1: Planning A1 with a suitability level of $79.87 \%$; No.2: planning A2, with a suitability level of 79.19\%; No. 4: Planning A4 with a $77.03 \%$ suitability level; No. 6: organizing A2, with a suitability level of $76.35 \%$; No.7: Organizing $\mathrm{A}_{3}$, with a suitability level of $79.45 \%$; and no.12: implementation of $\mathrm{A}_{4}$, with a suitability level of $75.17 \%$. At YPHB, the overall quality performance in the management standards is in the very good category. The $\mathrm{A}_{3}$ Implementation Attribute exceeds the suitability level, which is $100.68 \%$. Overall, the quality performance of the teacher and education staff standards is in the very good category. In all the actuating attributes $\mathrm{Al}_{1}-\mathrm{A}_{4}$ has a maximum quality performance of $100 \%$ each. In general, the quality performance in management standards is very good. There is even one attribute in All actuating $A_{3}$ that exceeds its suitability level, which is $100.68 \%$.

To determine the importance of the performance index (IPA), then make a quadrant analysis by presenting the average performance rating and importance (Importance) for each attribute as can be seen in table 8. Performance levels in 4 management functions and 16 attributes (questions) were obtained by dividing the performance score by the number of all respondents. The performance score on 4 management functions and 16 attributes is the total number of answers from 30 respondents with each question according to the Likert scale, namely 1 to 5 with the total number of attributes or questions as many as 16 attributes (questions)

Table 8: The average performance level assessment of Performance (Xi) and the level of importance (Yi) for each attribute in the Management Standards.

\begin{tabular}{|c|c|c|c|c|c|c|c|c|c|c|c|c|c|c|}
\hline \multirow{3}{*}{ POAC } & \multirow{3}{*}{ No } & \multirow{3}{*}{ Attribute } & \multicolumn{4}{|c|}{$\begin{array}{l}\text { Management } \\
\text { Standards }\end{array}$} & \multicolumn{4}{|c|}{$\begin{array}{c}\text { Competency of } \\
\text { Graduate Standards }\end{array}$} & \multicolumn{4}{|c|}{$\begin{array}{c}\text { Educator and } \\
\text { Education Standards }\end{array}$} \\
\hline & & & \multicolumn{2}{|c|}{ Ummul Quro } & \multicolumn{2}{|c|}{ YPHB } & \multicolumn{2}{|c|}{ Ummul Quro } & \multicolumn{2}{|c|}{ YPHB } & \multicolumn{2}{|c|}{ Ummul Quro } & \multicolumn{2}{|c|}{ YPHB } \\
\hline & & & $(\mathrm{Xi})$ & (Yi) & $(\mathrm{Xi})$ & (Yi) & $(\mathrm{Xi})$ & (Yi) & $(\mathrm{Xi})$ & $(\mathrm{Yi})$ & $(\mathrm{Xi})$ & $(\mathrm{Yi})$ & $(\mathrm{Xi})$ & $(\mathrm{Yi})$ \\
\hline \multirow{4}{*}{ Planning } & 1 & $\mathrm{Al}_{1}$ & 4,63 & 5,00 & 4,90 & 5,00 & 4,43 & 4,43 & 4,73 & 5,00 & 3,97 & 4,97 & 4,70 & 5,00 \\
\hline & 2 & A2 & 4,60 & 4,97 & 4,97 & 5,00 & 4,43 & 4,43 & 4,73 & 5,00 & 3,93 & 4,97 & 4,70 & 5,00 \\
\hline & 3 & $\mathrm{~A}_{3}$ & 4,40 & 4,97 & 5,00 & 5,00 & 4,20 & 4,20 & 4,67 & 5,00 & 4,03 & 4,93 & 4,67 & 5,00 \\
\hline & 4 & $\mathrm{~A}_{4}$ & 4,37 & 4,97 & 5,00 & 5,00 & 4,27 & 4,27 & 4,60 & 5,00 & 3,80 & 4,93 & 4,67 & 5,00 \\
\hline
\end{tabular}




\begin{tabular}{|c|c|c|c|c|c|c|c|c|c|c|c|c|c|c|}
\hline \multirow{4}{*}{ Organizing } & 5 & $\mathrm{~A}_{1}$ & 4,30 & 4,93 & 4,87 & 5,00 & 4,17 & 4,17 & 4,70 & 5,00 & 4,30 & 4,93 & 4,23 & 5,00 \\
\hline & 6 & $\mathrm{~A}_{2}$ & 3,80 & 4,97 & 4,93 & 5,00 & 4,17 & 4,17 & 4,70 & 5,00 & 3,77 & 4,93 & 4,97 & 5,00 \\
\hline & 7 & $\mathrm{~A}_{3}$ & 3,90 & 4,90 & 4,90 & 5,00 & 4,20 & 4,20 & 4,67 & 5,00 & 3,87 & 4,87 & 4,97 & $5, \mathrm{oo}$ \\
\hline & 8 & $\mathrm{~A}_{4}$ & 3,93 & 4,87 & 4,87 & 5,00 & 4,00 & 4,00 & 4,47 & 5,00 & 4,10 & 4,90 & 4,97 & 5,00 \\
\hline \multirow{4}{*}{ Actuating } & 9 & $\mathrm{Al}_{1}$ & 3,97 & 4,83 & 4,97 & 5,00 & 4,03 & 4,03 & 4,60 & 5,00 & 4,00 & 4,87 & 5,00 & 5,00 \\
\hline & 10 & $\mathrm{~A} 2$ & 3,97 & 4,90 & 4,97 & 5,00 & 4,07 & 4,07 & 4,63 & 5,00 & 4,17 & 4,87 & 5,00 & 5,00 \\
\hline & 11 & $A_{3}$ & 4,20 & 4,73 & 4,97 & 4,93 & 4,07 & 4,07 & 4,50 & 5,00 & 4,20 & 4,93 & 5,00 & 5,00 \\
\hline & 12 & $\mathrm{~A}_{4}$ & 4,17 & 4,73 & 5,00 & 5,00 & 4,27 & 4,83 & 4,50 & 5,00 & 3,63 & 4,83 & 5,00 & 5,00 \\
\hline \multirow{4}{*}{ Controlling } & 13 & $\mathrm{Al}_{1}$ & 4,17 & 4,77 & 4,90 & 5,00 & 4,20 & 4,80 & 4,30 & 5,00 & 4,27 & 4,80 & 4,77 & 5,00 \\
\hline & 14 & $\mathrm{~A}_{2}$ & 4,13 & 4,83 & 4,87 & 5,00 & 4,13 & 4,87 & 4,47 & 5,00 & 4,20 & 4,87 & 4,50 & 5,00 \\
\hline & 15 & $\mathrm{~A}_{3}$ & 3,97 & 4,83 & 4,67 & 5,00 & 4,17 & 4,87 & 4,13 & 5,00 & 4,17 & 4,87 & 4,57 & 5,00 \\
\hline & 16 & $\mathrm{~A}_{4}$ & 3,87 & 4,83 & 4,60 & 5,00 & 4,43 & 4,83 & 4,03 & 5,00 & 3,93 & 4,77 & 4,20 & 5,00 \\
\hline Amount & & & 66,38 & 78,03 & 78,39 & 79,93 & 67,24 & 77,03 & 72,43 & 80,00 & 64,34 & 78,24 & 75,92 & 80,00 \\
\hline Average & & & 4,15 & 4,88 & 4,89 & 4,99 & 4,20 & 4,39 & 4,53 & 5 & 4,02 & 4,89 & 4,75 & 5 \\
\hline
\end{tabular}

The management standards for UQ have an average level of performance (Xi) of 4.15 and an average level of importance (Yi) of 4.88 , while at YPHB, the average level of performance (Xi) is 4.89 and average - average for importance level (Yi) 4.99. The competency standards for Ummul Quro graduates have an average level of performance (Xi) of 4.20 and an average level of importance (Yi) of 4.39, while at YPHB, the average level of performance (Xi) is 4.53 and the average for the level of importance (Yi) 5.0o. The average for the Performance Level (Xi) is 4.20 and the average for the level of importance (Yi) is 4.39. In teacher and education staff standards, at Ummul Quro, the average for the Performance Level ( $\mathrm{Xi}$ ) is $\mathbf{4 . 0 2}$, and the average for the level of importance (Yi) is 4.89 . Meanwhile, the standards of teacher and education staff at YPHB have an average level of performance (Xi) of 4.75, and the average for the level of importance (Yi) is 5.0o.

\section{Implementation Based on the Importance Performance Analysis (IPA) Model}

The management standards for Ummul Quro have an average level of performance (Xi) of 4.15 and an average level of importance (Yi) of 4.88 , while at YPHB, the average level of performance (Xi) is 4.89 and average for importance level (Yi) 4.99. The competency standards for Ummul Quro graduates have an average level of performance (Xi) of 4.20 and an average level of importance (Yi) of 4.39, while at YPHB, the average level of performance (Xi) is 4.53 and the average for the level of importance (Yi) 5.0o. The average for the Performance Level (Xi) is 4.20 and the average for the level of importance (Yi) is 4.39. In teacher and education staff standards, at Ummul Quro, the average for the performance level $(\mathrm{Xi})$ is $\mathbf{4 . 0 2}$, and the average for the level of importance ( $\mathrm{Yi}$ ) is 4.89 . Meanwhile, the standards of teacher and education staff at YPHB have an average level of performance (Xi) of 4.75, and the average for the level of importance (Yi) is 5.0o.

Table 9: Decision-Making Quadrant on Management Standards, Competency Standards for Graduates and Teacher and Education Staff Standards

\begin{tabular}{|c|c|c|c|c|}
\hline \multirow{3}{*}{$\begin{array}{c}\text { Management } \\
\text { Standards }\end{array}$} & \multicolumn{2}{|c|}{ Ummul Quro } & \multicolumn{2}{|c|}{ YPHB } \\
\hline & $\begin{array}{c}\text { Quadrant I } \\
\text { NA } 6 \text { Organizing A2 } \\
\text { NA } 7 \text { Organizing A3 } \\
\text { NA } 10 \text { Actuating A2 }\end{array}$ & $\begin{array}{c}\text { Quadrant II } \\
\text { NA } 1 \text { Planning A1 } \\
\text { NA } 2 \text { Organizing A2 } \\
\mathrm{NA}_{3} \text { Planning A } \\
\mathrm{NA}_{4} \text { Planning } \mathrm{A}_{4} \\
\mathrm{NA}_{5} \text { Organizing A }\end{array}$ & $\begin{array}{c}\text { Quadrant I } \\
\text { NA } 1 \text { Planning A1 } \\
\text { NA } 5 \text { Organizing A } 1 \\
\text { NA } 8 \text { Organizing A4 NA } 14 \\
\text { Controlling A2 } \\
\text { NA }_{15} \text { Controlling A } \text { NA }_{16} \\
\text { Controlling A4 }\end{array}$ & $\begin{array}{c}\text { Quadrant II } \\
\text { NA } 2 \text { Planning A2 } \\
\mathrm{NA}_{3} \text { Organizing A3 } \\
\mathrm{NA}_{4} \text { Organizing A4 } \\
\mathrm{NA}_{6} \text { Organizing A2 } \\
\mathrm{NA}_{7} \text { Organizing A3 } \\
\text { NA } 9 \text { Actuating A1 } \\
\mathrm{NA}_{10} \text { Actuating A2 } \\
\text { NA } 13 \text { Actuating A4 } \\
\text { NA } 13 \text { Controlling } \mathrm{A}_{1}\end{array}$ \\
\hline & \begin{tabular}{|c} 
Quadrant III \\
NA 8 Organizing A4 \\
NA 9 Actuating A1 \\
NA 14 Controlling A2 \\
NA 16 Controlling A4
\end{tabular} & $\begin{array}{c}\text { Quadrant IV } \\
\text { NA } 11 \text { Actuating A } 3 \\
\text { NA } 12 \text { Actuating A4 } \\
\text { NA }_{13} \text { Controlling A } 1\end{array}$ & $\begin{array}{l}\text { Quadrant III } \\
\text { No NA }\end{array}$ & $\begin{array}{c}\text { Quadrant IV } \\
\text { NA } 11 \text { Actuating } A_{3}\end{array}$ \\
\hline
\end{tabular}




\begin{tabular}{|c|c|c|c|c|}
\hline & \multicolumn{2}{|c|}{ Ummul Quro } & \multicolumn{2}{|r|}{ YPHB } \\
\hline \multirow[t]{2}{*}{$\begin{array}{l}\text { Competency of } \\
\text { Graduate } \\
\text { Standards }\end{array}$} & $\begin{array}{c}\text { Quadrant I } \\
\text { NA } 3 \text { Planning A3 } \\
\text { NA } 11 \text { Actuating A3 } \\
\text { NA }_{14} \text { Controlling A2 } \\
\text { NA }_{15} \text { Controlling } A_{3}\end{array}$ & $\begin{array}{c}\text { Quadrant II } \\
\text { NA } 1 \text { Planning A1 } \\
\text { NA } 2 \text { Planning A2 } \\
\text { NA } 4 \text { Planning A4 } \\
\text { NA } 12 \text { Actuating A4 } \\
\text { NA } 16 \text { Controlling A4 }\end{array}$ & $\begin{array}{l}\text { Quadrant I } \\
\text { No NA }\end{array}$ & 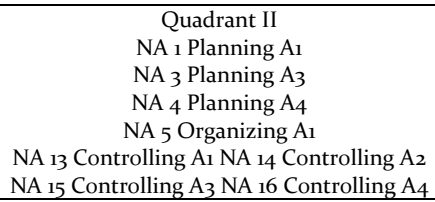 \\
\hline & $\begin{array}{l}\text { Quadrant III } \\
\text { NA } 5 \text { Organizing A1 } \\
\text { NA } 6 \text { Organizing A2 } \\
\text { NA } 7 \text { Organizing A } \\
\text { NA } 8 \text { Organizing A4 } \\
\text { NA } 9 \text { Actuating A1 } \\
\text { NA } 10 \text { Actuating A2 } \\
\text { NA } 13 \text { Controlling A1 }\end{array}$ & $\begin{array}{c}\text { Quadrant IV } \\
\text { No NA }\end{array}$ & $\begin{array}{c}\text { Quadrant III } \\
\text { No NA }\end{array}$ & $\begin{array}{c}\text { Quadrant IV } \\
\text { NA } 2 \text { Planning A2 } \\
\text { NA } 6 \text { Organizing A2 } \\
\mathrm{NA}_{7} \text { Organizing } \mathrm{A}_{3} \\
\mathrm{NA} 8 \text { Organizing A4 } \\
\mathrm{NA} 9 \text { Actuating A1 } \\
\mathrm{NA} 10 \text { Actuating } \mathrm{A}_{2} \\
\mathrm{NA} 11 \text { Actuating } \mathrm{A}_{3} \\
\mathrm{NA} 12 \text { Actuating } \mathrm{A}_{4}\end{array}$ \\
\hline \multirow[t]{2}{*}{$\begin{array}{l}\text { Educator and } \\
\text { Education } \\
\text { Standards }\end{array}$} & $\begin{array}{c}\text { Quadrant I } \\
\text { NA } 1 \text { Planning A1 } \\
\text { NA } 2 \text { Planning A2 } \\
\text { NA } 4 \text { Planning A4 } \\
\text { NA } 6 \text { Organizing A2 }\end{array}$ & $\begin{array}{c}\text { Quadrant II } \\
\text { NA } 3 \text { Planning A3 } \\
\text { NA } 5 \text { Organizing A1 } \\
\text { NA } 8 \text { Organizing A4 } \\
\text { NA } 11 \text { Actuating A } 3\end{array}$ & $\begin{array}{l}\text { Quadrant I } \\
\text { No NA }\end{array}$ & $\begin{array}{c}\text { Quadrant II } \\
\text { NA } 1 \text { Planning A1 } \\
\mathrm{NA}_{3} \text { Planning A3 } \\
\mathrm{NA}_{7} \text { Organizing A3 } \\
\text { NA } 8 \text { Organizing A4 } \\
\mathrm{NA}_{1} 10 \text { Actuating A2 } \\
\mathrm{NA}_{11} \text { Actuating A3 } \\
\mathrm{NA}_{13} \text { Controlling A1 } \\
\mathrm{NA}_{14} \text { Controlling A2 } \\
\mathrm{NA}_{15} \text { Controlling A3 } \\
\text { NA } 16 \text { Controlling A4 }\end{array}$ \\
\hline & $\begin{array}{c}\text { Quadrant III } \\
\text { NA } 7 \text { Organizing A3 } \\
\text { NA } 9 \text { Actuating A1 } \\
\text { NA } 12 \text { Actuating A4 } \\
\text { NA } 16 \text { Controlling A4 }\end{array}$ & \begin{tabular}{|c|} 
Quadrant IV \\
NA 10 Actuating A2 \\
NA 13 Controlling A1 \\
NA $_{14}$ Controlling A2 \\
NA $_{15}$ Controlling A3
\end{tabular} & $\begin{array}{c}\text { Quadrant III } \\
\text { No NA }\end{array}$ & $\begin{array}{c}\text { Quadrant IV } \\
\text { NA } 2 \text { Planning A2 } \\
\text { NA } 4 \text { Planning A4 } \\
\text { NA } 5 \text { Organizing A1 } \\
\text { NA } 6 \text { Organizing A2 } \\
\text { NA } 9 \text { Actuating A1 } \\
\text { NA } 12 \text { Actuating } A_{4} \\
\end{array}$ \\
\hline
\end{tabular}

Table 9 shows the distribution of the implementation of 3 SNPs in quadrants to find out what the best decisions can be made based on the importance-performance analysis (IPA) model. Based on the distribution in quadrants 1 to 4 , it can be explained that in the management standards of the Ummul Quro, the attributes that are in quadrant I where the institution prioritizes to improve the quality of performance, including number 6 organizing A2: Compilation of the respective duties/jobs. functions/sections, number 7 organizing $A_{3}$ : Socialization of the foundation/school management system and number 10 actuating A2: use of work mechanisms/procedures/instructions in carrying out work. Attributes that are in quadrant II where the institution must maintain the quality of its performance are attribute number 1 planning A1: Formulation of vision and mission, number 2 planning A2: Setting goals, number 3 planning A3: Formulating targets and strategic plans for the foundation and number 4 planning A4: Making program/work plan of the foundation and number 5 organizing A1: The design of the organizational structure of the foundation/school. The attributes that are in quadrant III where the institution must strive to maintain the stability of the quality of work, namely: number 8 organizing A4: Coordinating between work fields in foundations/schools; number 9 Al implementation: Use of guidelines/provisions in carrying out tasks; number 14 supervision A2: Implementation of supervision of the work of each division in the Foundation / School; number 15: Supervision A3: Implementation of evaluation of the achievement of targets and main duties and functions of all divisions in the Foundation / School; number 16 supervision A4: Preparation of reports and recommendations for follow-up. The attributes that are in quadrant IV of excess (Possible Overkill) where the institution maintains stability in the level of satisfaction with the quality of performance is number 11 implementation $A_{3}$ : Implementation of activities according to the agreed program; number 12 Implementation A4: Involvement of community participation and partnerships/school committees; nor 13 Supervision A1: Monitoring the implementation of the program/work plan of each division in the Foundation / School. 
The competency standards of graduates, how the institution prioritizes improving the quality of performance attributes in showed in quadrant I, namely: number 3 planning A3: Determining SKL achievement targets, number 11 implementing A3: Implementing SKL in the form of programs and activities, number 14: Supervision A2: Evaluation of SKL achievement, number 15 supervision A3: Reporting the achievement of SKL. Institutions must maintain the quality of performance attributes in quadrant II, namely: number 1 planning A1: Determination of comprehensive SKL points (attitudes, knowledge, and skills); number 2 planning A2: Preparation of indicators from its SKL points, number 4 planning $\mathrm{A}_{4}$ : Determining the form and method of evaluation and evaluation; number 12 implementation $\mathrm{A}_{4}$ : Recording SKL achievement, number 16 supervision $\mathrm{A}_{4}$ : Determine the status of achievement and make recommendations for follow-up. The institution continues to strive to maintain the stability of the performance quality of the attributes in quadrant III, namely: number 5 organizing A1: Determining the structure of the person in charge of SKL formulation in foundations/schools, number 6 organizing A2: Determining the SKL formulating team, number 7 organizing A3: Division of formulation and preparation of SKL, number 8 Organizing A4: Determination of reference sources, guidelines, and mechanisms for formulating/drafting SKL, number 9 Implementation Ar: Formulation/compilation of SKL according to the target time; number 10 A2 implementation: Socialization of the approved SKL formulation, number 13 A1 supervision: Supervision of program implementation and SKL achievement activities. There are no attributes in quadrant IV.

The standards of teacher and education staff, the institution prioritizes improving the quality of performance attributes in quadrant I, namely number 1 planning A1: Preparation of personnel guidelines and regulation, number 2 planning A2: Formulating admission mechanisms, management, dismissal of human resources, number 4 planning A4: Submission of the needs of teacher and education staff according to the results of the analysis, number 6 organizing Az: Socialization of policies, guidelines, and personnel regulations. Institutions must maintain the quality of performance attributes in quadrant II, namely: number 3 planning A3: Determination of qualifications and competencies of teacher and education Staff, number 5 organizing Al: Agreement and work commitment, number 8 organizing A4: Coordinating the implementation of education, training, number 11 implementation of $A_{3}$ : The institution continues to strive to maintain the stability of the performance quality of the attributes in quadrant III, namely: number 7 organization A3: Explanation of the structure of the unit/section, and the main tasks and functions.

Based on the scientific analysis, several things that are indicators of implementation that provide an assessment that exceeds the standard based on the best performance among the two schools tested in this sample are the aspects of program implementation, academic service mechanisms, the quality of human resources as actors including the application through a reward and punishment system. Enjoyable academic services for students is the availability of sufficient consultation time provided by the school to parents in monitoring student development. Other academic services such as availability of syllabus, facility, teacher and student and sharing information still relatively low (Saggaf et al., 2017). This is consistent with previous research which states that some of the most important factors in the service aspect are the programs implemented, human resources who work to provide services and infrastructure, or the physical environment. If the service aspect satisfies the customer, then the physical environmental factor is no longer an important factor because it has been replaced by satisfaction in service (Yildiz, 2011).

\section{Conclusion}

In the world of education today, where the competition between schools is very high, the demand for accreditation that reflects the real conditions of learning activities at school and its supporting aspects must be faced and the involvement of technology in learning cannot be negotiated, then the goal that focuses on quality is the thing that becomes a priority. The UQ and YPHB as Islamic senior high schools continue to strive towards achieving their best by the existing government guidelines 
and spelled out in the national education standards. The implementation of national education standards in the aspects of management, competence of graduates, and teacher and education staff standards in UQ and YPHB Islamic senior high schools are supported by policies, regulations, a management system with complete and detailed tools through their vision, mission, goals, targets, annual policy, organizational structure, main tasks, procedures/mechanisms, documentation. Based on the test using the IPA model in the implementation of the three national education standards, both UQ and YPHB have very good suitability between importance and performance, but based on the mean difference test, the mean YPHB suitability was higher than UQ significantly at $5 \%$ alpha.

The distribution of the implementation of 3 SNPs is shown to find out what is the best decisions can be made based on the importance-performance analysis (IPA) model. This study provides an overview of a better understanding of service quality factors based on empirical analysis using a sample of high school UQ and YPHB. Based on the results of this study, to provide the best service quality and performance, Islamic education institutions must strive to improve performance through compilation of the respective duties, job description, use of work mechanisms/procedures and socialization management system, formulation vision and mission, design of the organizational structure, coordination between fields of work, implementation of supervision of the work of each division in the foundation, implementation of evaluation of the achievement of targets and main tasks and functions of all divisions, preparation of reports and recommendations for follow-up. Several things that can be improved regarding the competence of graduates are implementing SKL in the form of programs and activities, determining, evaluating, and reporting SKL achievement targets. Meanwhile, things that need to be improved regarding teachers and education personnel are preparation and socialization of personnel guidelines and regulations, formulating admission mechanisms, management, dismissal, submission of the needs of teachers and education staff according to the results of the analysis.

The school must maintain several attributes that have been assessed as good, such as formulate vision and mission, goals, targets and strategic plans, making program, design of the organizational structure, compilation of the main tasks and functions, mechanisms/procedures in carrying out tasks, use of guidelines/provisions, involvement of community participation and partnerships/school committees, monitoring the implementation of programs/work plans of each division. Related to the competency standards of graduates, some of the attributes whose performance is maintained, among others, determine comprehensive SKL points, preparation of indicators from its SKL points, determining the form and method of evaluation and evaluation, recording SKL achievement, determine the status of achievement and make recommendations for follow-up. To maintain the good performance of teachers and education personnel, some things that need to be considered determine the qualifications and competencies, agreement and work commitment, coordinating the implementation of education, training, and coaching, the presence and performance, preparation of personnel guidelines, and regulations, explanation of the structure of the unit/ section, and the main tasks and functions of employees, optimal implementation of the duties of monitoring the implementation of teacher and education staff, supervising the implementation of the work/tasks of educators and educational staff periodically; Periodic evaluation of the implementation of the work, compiling reports and making recommendations for follow-up.

There are not many UQ and YPHB attributes that are in quadrant III which are factors that present attributes that are not important and also unsatisfactory. These variables are coordinating between work fields, use of guidelines/provisions in carrying out tasks; implementation of supervision of the work of each division, implementation of evaluation of the achievement of targets and main duties and functions, preparation of reports, and recommendations for follow-up. As illustrated in quadrant IV, the institution maintains the stability of the level of satisfaction with the quality of the performance, implementation of activities according to the agreed program, involvement of community participation and partnerships/school committees, monitoring the implementation of the program, the competency standards of graduates. The best quality of SKL that give satisfaction is determining the division of tasks, formulating team, the person in charge of 
preparation SKL formulation, determination of reference sources, guidelines, and mechanisms for formulating/drafting SKL, a compilation of SKL according to the target time, socialization of the approved and legalized SKL formulation, supervision of program implementation and SKL achievement activities, determination of comprehensive SKL points (attitudes, knowledge, and skills), determining SKL achievement targets, determining the form and method of evaluation and evaluation, supervising the implementation of programs and activities to achieve SKL, evaluation of SKL achievement, reporting, recording the achievement of SKL, make recommendations for followup. Proposing needs teacher and education staff the institution maintains the stability of the level of satisfaction with the quality of the performance according to the results of the analysis; number Agreement and work commitment, socializing policies, guidelines and personnel regulations to teacher and education staff, competency development (pedagogic, personality, professional, and social) principals, educators, educational staff, and other departments periodically, consistent application of reward and punishment are the attribute of teacher and education staff that the institution has to maintains the stability of the level of satisfaction with the quality of the performance.

This study has limitations, especially related to the object of research which is only two schools and 30 respondents. With a limited number of samples, statistical testing is constrained to find significant relationships from the data because it usually requires a larger sample size to ensure a representative distribution of the population and to be considered representative of the group of people whose results will be generalized or transferred.

\section{References}

Akhil, A., \& Suresh, M. (2021). Assessment of service quality in a restaurant using multi-grade fuzzy and importance-performance analysis. Materials Today: Proceedings, 3. https://doi.org/10.1016/j.matpr.2021.01.7 67

Alberty, S., \& Mihalik, B. J. (1989). The Use of Importance-Performance Analysis as an Evaluative Technique in Adult Education. Sage Journal, 13(1), 33-44. https://doi.org/10.1177/0193841X8901300103

Amoli, S. J., \& Aghashahi, F. (2016). An Investigation on Strategic Management Success Factors in an Educational Complex. Procedia - Social and Behavioral Sciences, 23o(May), $447-454$. https://doi.org/10.1016/j.sbspro.2016.09.056

Anafinova, S. (2020). The role of rankings in higher education policy: Coercive and normative isomorphism in Kazakhstani higher education. International Journal of Educational Development, 78(May), 102246. https://doi.org/10.1016/j.ijedudev.2020.102246

Anwar, H. (2018). Implementation of education management standards in the guidance of private Islamic high schools. Jurnal Pendidikan Islam, 4(1), 75-86. https://doi.org/10.15575/jpi.v4i1.2250

Badrudin, B. (2017). Indonesia's Educational Policies on Madrasah Diniyah (MD). Jurnal Pendidikan Islam, 3 (1), 17. https://doi.org/10.15575/jpi.v3i1.850

Chi-Cheng Chang. (2014). An IPA-embedded model for evaluating creativity curricula. Innovations in Education and Teaching International, 51(1), 59-71. https://doi.org/10.1080/14703297.2013.856144

Das, A., \& Basu, T. (2020). Assessment of peri-urban wetland ecological degradation through importanceperformance analysis (IPA): A study on Chatra Wetland, India. Ecological Indicators, 114. https://doi.org/10.1016/j.ecolind.2020.106274

De Jesus Henriques Silva, F., \& Fernandes, P. O. (2011). Importance-performance analysis as a tool in evaluating higher education service quality: The empirical results Of testing (IPB). Creating Global Competitive Economies: A 360-Degree Approach - Proceedings of the 17th International Business Information Management Association Conference, IBIMA 2011, 4(August 2015), 306-315.

Hapsari, D., Riyanto, S. \& Endri, E. (2021). The Role of Transformational Leadership in Building Organizational Citizenship: The Civil Servants of Indonesia. Journal of Asian Finance, Economics, and Business, 8(2), 595604. https://doi.org/10.13106/jafeb.2021.vol8.no2.0595

Hsiu Yuan Hu, Yu Cheng Lee, Tieh Min Yen, \& Chih Hung Tsaic. (2009). Using BPNN and DEMATEL to modify importance-performance analysis model - A study of the computer industry. Expert Systems with Applications, 36(6), 9969-9979. https://doi.org/10.1016/j.eswa.2009.01.062. 
Ivan, S. (2015). Importance-performance analysis: A valid management tool? Tourism Management, 48, 45-53. DOI: 10.1016/j.tourman.2014.10.022

Javad, E. pour, Kayvan, A., Mohammad, A. V., \& ChrisDe, G. (2020). Importance - Performance Analysis (IPA) of bus service attributes: A case study in a developing country. Transportation Research Part A: Policy and Practice, 142, 129-150. https://doi.org/10.1016/j.tra.2020.10.020.

Lakkoju, S. (2016). Importance-Performance Analysis of Service Quality in Higher Education: A Case Study. Indian Journal of Industrial Relations, 52(1), 144-1556. http://www.jstor.org/stable/43974604

Markazi-Moghaddam, N., Kazemi, A., \& Alimoradnori, M. (2019). Using the importance-performance analysis to improve hospital information system attributes based on nurses' perceptions. Informatics in Medicine Unlocked, 17 (September), 100251. https://doi.org/10.1016/j.imu.2019.100251

Martilla, J. A., \& James, J.C. (1977). Importance-performance analysis. Journal of Marketing (pre-1986), 41, 77-79

Mujahidin, E., \& Hartono, R. (2020). The Role of Leader Assessment in Developing Teacher Teams in the Industrial Revolution 4.o. International Journal of Innovation, Creativity, and Change. 13(7), 838-852.

Noviyanti, M., Sudarwo, R., Mardiana, A., \& Hendra Budima, M. (2018). the Importance-Performance Analysis (Ipa) on Academic and Non-Academic Services To Enhance Student Motivation. 6(1), 78-88.

OECD, \& ADB. (2015). Education in Indonesia: Rising to the Challenge. In Far Eastern Survey (Vol. 20 ).

Retrieved from http://www.adb.org/sites/default/files/publication/156821/education-indonesia-risingchallenge.pdf.

Ormanovic, S., Ciric, A., Talovic, M., Alic, H., Jeleskovic, E., \& Causevic, D. (2017). Importance-performance analysis: different approaches. Acta kinesiological, 11, 58-66.

Pahala, Y., Widodo, S., Kadarwati., Azhari, M., Muliyati., Lestari, N.I., Madjid, S.A., Sidjabat, S., Limakrisna, N., \& Endri, E. (2021). The effects of service operation engineering and green marketing on consumer buying interest. Uncertain Supply Chain Management, 9(3), 603-6o8. https://doi: 10.5267/j.uscm.2021.5.011

Rusdiana, A., \& Nasihudin, N. (2018). The Implementation of National Standard-Based Curriculum in Private Islamic Higher Education: Leadership Impact. Jurnal Pendidikan Islam, 4(1), 87-98. https://doi.org/10.15575/jpi.v4i1.2116

Saggaf, M. S., Salam, R., Darwis, M., \& Jamaluddin, M. (2017). Examining Academic Service using Importance Performance Analysis (IPA). 149(Icest), 139-141. https://doi.org/10.2991/icest-17.2017.47

Sebayang, K. D. A., \& Swaramarinda, D. R. (2020). Educational policy implementation in Indonesia: The art of decision making. International Journal of Scientific and Technology Research, 9(1), 1286-1290.

Silitonga, T.B., Sujanto, B., Luddin, M. R., \& Susita, D., \& Endri, E. (2020). Evaluation of Overseas Field Study Program at the Indonesia Defense University. International Journal of Innovation, Creativity, and Change, 12(10), 554-573.

Sidik, W. A., Sunardi, \& Supriyanto. (2019). Importance-Performance Analysis and Student Satisfaction Index on Laboratory Services in the Faculty Mathematics and Natural Sciences, Universitas Jenderal Soedirman. IOP Conference Series: Earth and Environmental Science, 255(1). https://doi.org/10.1088/1755-1315/255/1/012031

Susanto, Y., Nuraini., Sutanta., Gunadi., Basrie., Mulyadi., \& Endri, E. (2020). The Effect of Task Complexity, Independence and Competence on the Quality of Audit Results with Auditor Integrity as a Moderating Variable. International Journal of Innovation, Creativity, and Change, 12(12), 742-755.

Virgiawan, A. R., Riyanto, S., \& Endri, E. (2021). Organizational Culture as a Mediator Motivation and Transformational Leadership on Employee Performance. Academic Journal of Interdisciplinary Studies, 10(3), 67. https://doi.org/10.36941/ajis-2021-0065

Wahyuni, S. (2016). Curriculum Development in Indonesia Context the Historical Perspectives and the Implementation. Universum, 10(1), 73-82.

Wong, M. S., Hideki, N., \& George, P. (2011). The Use of Importance-Performance Analysis (IPA) in Evaluating Japan's E-government Services. Journal of Theoretical and Applied Electronic Commerce, 6(2). 17-30. DOI: 10.4067/So718-18762011000200003

Yildiz, S. M. (2011). An importance-performance analysis of fitness center service quality: Empirical results from fitness centers in Turkey. African Journal of Business Management, 5(16), $7031-7041$. https://doi.org/10.5897/AJBM11.674 